\title{
POLA PEMENUHAN KEBUTUHAN KONSUMSI PANGAN HEWANI DARI JENIS IKAN DI INDONESIA
}

\section{PATTERN OF FULFILLMENT OF ANIMAL FOOD CONSUMPTION NEEDS FROM FISH TYPES IN INDONESIA}

\author{
YENYEN HUSNAYAEN ${ }^{1}$, ERI CAHRIAL ${ }^{2}$, HENDAR NURYAMAN ${ }^{2 *}$, \\ ENOK SUMARSIH ${ }^{2}$ \\ ${ }^{\mathbf{1}}$ Fakultas Pertanian, Universitas Siliwangi \\ ${ }^{2}$ Staff Pengajar, Fakultas Pertanian, Universitas Siliwangi \\ *E-mail Corresponding: hendarnuryaman@unsil.ac.id
}

\begin{abstract}
ABSTRAK
Penelitian ini bertujuan untuk mengidentifikasi pola konsumsi serta menganalisis tingkat keragaman dan keseimbangan konsumsi pangan hewani penduduk Indonesia menurut wilayah perkotaan dan perdesaan, kemudian mengidentifikasi peranan ikan dalam pemenuhan kebutuhan konsumsi pangan hewaninya. Metode penelitian menggunakan studi kasus yang merupakan bagian dari studi deskriptif dengan teknik studi literatur berdasarkan data Survei Sosial Ekonomi Nasional (Susenas) tahun 20192020. Hasil penelitian memperlihatkan bahwa pola konsumsi pangan hewani di Indonesia pada tahun 2019-2020 adalah ikan-daging-telur-susu baik di wilayah perkotaan maupun perdesaan. Tingkat keragaman dan keseimbangan konsumsi pangan hewani di Indonesia masih belum ideal (PPH pangan hewani <24), dimana kelompok kategori rendah mendominasi masyarakat perdesaan sedangkan kelompok kategori cukup mendominasi masyarakat perkotaan. Pangan ikan berperan dalam upaya pemenuhan kebutuhan konsumsi pangan hewani di Indonesia baik di wilayah perkotaan maupun di wilayah perdesaan, dimana tingkat konsumsi ikan merupakan yang tertinggi dibandingkan konsumsi pangan hewani lainnya.
\end{abstract}

Kata Kunci: Pola konsumsi pangan hewani, Konsumsi ikan, Energi dan Protein

\begin{abstract}
This study aims to identify consumption patterns and analyze the level of diversity and balance of animal food consumption of the Indonesian population according to urban and rural areas, as well as identify and trace the role of fish in fulfilling their animal food consumption needs. The research method used is a case study which is part of a descriptive study with a literature study technique based on data from the 2019-2020 National Socio-Economic Survey (Susenas). The results of the study show that the pattern of animal food consumption in Indonesia in 2019-2020 is fish-meat-egg-milk in both urban and rural areas. The level of diversity and balance of animal food consumption in Indonesia is still not ideal (PPH animal food <24), where the low category group dominates the rural community while the category group moderately dominates the urban community. Fish food plays a role in efforts to meet the needs of animal food consumption in Indonesia. Both in urban areas and in rural areas, the level of fish consumption is the highest compared to consumption of other animal foods.
\end{abstract}

Keywords: Animal food consumption pattern, Fish consumption, Energy and Protein

\section{PENDAHULUAN}

Tingkat konsumsi rumah tangga merupakan salah satu komponen dalam pembentukan Produk Domestik Bruto (PDB) Indonesia. Perkembangan dari tahun ke tahun menunjukkan bahwa konsumsi rumah tangga selalu menjadi kontributor terbesar dalam pembentukan nilai PDB. Pengeluaran konsumsi rumah tangga digunakan untuk memenuhi berbagai 
pengeluaran konsumsi akhir atas barang dan jasa untuk memenuhi kebutuhan individu ataupun kelompok. Perilaku rumah tangga dalam mengonsumsi makanan dan bukan makanan untuk memenuhi kebutuhan sehari-hari merupakan salah satu hal yang dapat mencerminkan tingkat kesejahteraan masyarakat suatu negara (Wahyuni, dkk., 2016).

Data BPS $\left(2020^{\mathrm{a}}\right)$ memperlihatkan bahwa secara rata-rata telah terjadi penurunan dalam pendapatan rumah tangga di Indonesia, sehingga masyarakat perlu mengatur kembali pola konsumsinya untuk mencukupi kebutuhan dasar mereka.

Perbedaan tingkat pendapatan penduduk di perkotaan dan perdesaan menimbulkan tanggapan yang berbeda dalam upaya pemenuhan kebutuhan konsumsinya. Tingkat pendapatan memengaruhi akan pola konsumsi pangan, hal ini sesuai dengan Hukum Bennet yang menyatakan ketika orang menjadi lebih kaya, mereka cenderung beralih dari pola makan sederhana yang didominasi bahan pangan berpati ke input makanan yang lebih bervariasi yang mencakup berbagai sayuran, buah, produk susu, dan terutama daging (Godfray, 2011).

Tanzil dan Hafriani menyebutkan bahwa pendapatan keluarga yang rendah merupakan salah satu faktor resiko terjadinya stunting pada balita usia 24-59 bulan selain faktor dari kurangnya asupan energi dan protein, serta pengetahuan dan pendidikan ibu yang rendah.

Secara global, Indonesia masih termasuk ke dalam 50 negara dengan jumlah penderita kekurangan gizi terbesar pada tahun 2018. Untuk mencukupi kebutuhan gizi tersebut, maka konsumsi pangan perlu dipenuhi dari seluruh kelompok pangan, termasuk kelompok pangan hewani.

Kebutuhan akan pangan hewani bisa terpenuhi baik dari jenis ternak maupun ikan. Suryawati, dkk. $\left(2005^{\mathrm{a}}\right)$ mengemukakan bahwa ikan sangat berperan dalam menyumbang protein hewani di dalam mutu gizi makanan rumah tangga Indonesia pada masa pemulihan dari krisis moneter tahun 1997-1998. Selanjutnya Virgantari, dkk. (2011) menyatakan secara umum masyarakat dengan keterbatasan anggaran, lebih memberikan prioritas alokasi anggaran untuk produk perikanan dalam pemenuhan kebutuhan konsumsi pangan hewaninya pada tahun 2002-2008.

Pola konsumsi penduduk yang bersifat dinamis dan karakteristik lingkungan serta wilayah tempat dimana mereka tinggal seperti di perkotaan atau di 
perdesaan turut memengaruhi pola makanan yang dikonsumsi (BPS, 2020ª). Diperlukan kajian mengenai pola pemenuhan kebutuhan konsumsi terutama pangan hewani dimana jenis ikan merupakan titik fokusnya dikarenakan pada kasus-kasus sebelumnya ikan berkontribusi cukup nyata dalam pemenuhan kebutuhan konsumsi pangan hewani bagi masyarakat terutama pada masa krisis saat daya beli masyarakat terguncang.

Tujuan dari penelitian ini diantaranya untuk 1) mengidentifikasi pola konsumsi pangan hewani penduduk Indonesia, 2) menganalisis tingkat keragaman dan keseimbangan konsumsi pangan hewani di Indonesia, dan 3) mengidentifikasi peranan ikan dalam pemenuhan kebutuhan konsumsi pangan hewani di Indonesia. Dimana semuanya dibedakan berdasarkan wilayah perkotaan dan perdesaan.

\section{METODE PENELITIAN}

Penelitian ini menggunakan metode studi kasus yang merupakan bagian dari studi deskriptif dengan teknik studi literatur. Penelitian dilakukan dari Januari 2021-September 2021 dengan menggunakan data sekunder hasil Survei Sosial Ekonomi Nasional (Susenas) Badan Pusat Statistik tahun 2019-2020. Meliputi
34 provinsi dan 514 kabupaten/kota yang tersebar di seluruh wilayah Indonesia.

\section{HASIL DAN PEMBAHASAN}

\section{Pola Konsumsi Pangan Hewani}

Pola konsumsi pangan diartikan sebagai susunan makanan yang biasa atau secara teratur dan terus menerus dikonsumsi oleh masyarakat (Suryawati, dkk., 2005 a).

Tabel 1. Pola Konsumsi Pangan Hewani di Indonesia 2019-2020

\begin{tabular}{|c|c|c|c|c|}
\hline \multirow{2}{*}{$\begin{array}{c}\text { Wilayah } \\
\text { / } \\
\text { Tahun } \\
\end{array}$} & \multicolumn{4}{|c|}{$\begin{array}{l}\text { Tingkat Konsumsi } \\
\text { (kg/kapita/tahun) }\end{array}$} \\
\hline & Ikan & Daging & Telur & Susu \\
\hline \multicolumn{5}{|l|}{ Kota } \\
\hline 2019 & 19,77 & 9,28 & 7,57 & 6,07 \\
\hline 2020 & 19,23 & 9,57 & 7,65 & 6,32 \\
\hline \multicolumn{5}{|l|}{ Desa } \\
\hline 2019 & 19,91 & 6,15 & 5,86 & 2,97 \\
\hline 2020 & 19,92 & 6,38 & 6,14 & 3,02 \\
\hline \multicolumn{5}{|l|}{ Total } \\
\hline 2019 & 19,68 & 7,87 & 6,82 & 4,65 \\
\hline 2020 & 19,57 & 8,21 & 6,98 & 4,80 \\
\hline
\end{tabular}

Pola konsumsi pangan hewani di Indonesia tahun 2019-2020 adalah ikandaging-telur-susu. Tabel 1 memperlihatkan tidak terdapat perbedaan pola konsumsi pangan hewani pada tahun 2019 dan tahun 2020 secara wilayah. Namun, apabila dilihat dari proporsi konsumsi antar komoditasnya, terdapat perbedaan terutama dalam konsumsi daging dan susu.

Suryawati, dkk. $\left(2005^{\mathrm{a}}\right)$ menunjukkan bahwa pola konsumsi pangan hewani pada tahun 1996 adalah dagingikan-telur-susu dan terjadi perubahan pada 
tahun 1999 dan tahun 2002 yaitu menjadi ikan-daging-telur-susu.

Pergeseran preferensi konsumen untuk pangan hewani tersebut terjadi pada masa krisis ekonomi dan masa pemulihan yang menunjukkan bahwa daya beli masyarakat saat itu sedang terguncang.

\section{Secara keseluruhan tingkat} konsumsi pangan hewani tahun 2020 meningkat dibandingkan pada tahun sebelumnya, kecuali untuk komoditas ikan di wilayah perkotaan. Meskipun begitu, komoditas ikan memiliki tingkat konsumsi yang tinggi, dua sampai tiga kali lipat dari komoditas daging yang mana merupakan pangan hewani kedua tertinggi yang dikonsumsi baik itu di wilayah perkotaan maupun perdesaan.

\section{Tingkat Keragaman dan Keseimbangan}

\section{Konsumsi Pangan Hewani}

Indikator mutu gizi, keragaman, dan keseimbangan konsumsi pangan kelompok pangan hewani dapat ditinjau dari skor Pola Pangan Harapan (PPH).

Tabel 2. PPH Kelompok Pangan Hewani

\begin{tabular}{cccc}
\hline \multirow{2}{*}{ Tahun } & \multicolumn{3}{c}{ PPH Kelompok Pangan Hewani } \\
& Kota & Desa & Total \\
\cline { 2 - 4 } & 18,32 & 14,04 & 16,47 \\
2019 & 18,45 & 14,53 & 16,72 \\
\hline Sumber: BPS, 2019-2020 diolah (2021) &
\end{tabular}

Tabel 2 menunjukkan bahwa kualitas konsumsi kelompok pangan hewani di Indonesia masih belum ideal (skor PPH <24) baik di wilayah perkotaan maupun di wilayah perdesaan. Namun demikian, sedikit telah terjadi perbaikan keragaman dan keseimbangan konsumsi pangan hewani dilihat dari meningkatnya skor PPH kelompok pangan hewani pada tahun 2020 dibandingkan tahun sebelumnya.

Pada tahun 2007, PPH kelompok pangan hewani penduduk Indonesia hanya 12,09 (Lantarsih, dkk. 2011). Lebih lanjut Pertiwi, dkk. (2014) menemukan bahwa PPH kelompok pangan hewani anak usia 712 tahun mencapai 17,1. Bila ditinjau berdasarkan jenis kelamin, dimana pada anak perempuan lebih tinggi dibandingkan anak laki-laki yaitu 17,3 dan 16,9.

Studi lain Widodo, dkk. (2017) PPH kelompok pangan hewani anak usia 0,5-1,9 tahun mencapai 14,5. Adapun, $\mathrm{PPH}$ kelompok pangan hewani anak usia 2-5,9 tahun mencapai 18,3. Sedangkan, $\mathrm{PPH}$ kelompok pangan hewani anak usia 6-12,9 tahun mencapai 16,8.

Terdapat dua provinsi yang telah mencapai skor PPH ideal untuk kelompok pangan hewani yaitu kepulauan Riau dan kepulauan Bangka Belitung. Baik pada tahun 2019 maupun tahun 2020.

Apabila ditinjau berdasarkan wilayah ternyata di wilayah perdesaan di kedua provinsi tersebut masih belum 
mencapai target PPH ideal, dimana PPH pada tahun 2020 yaitu 20,53 untuk kepulauan Riau dan 21,74 untuk kepulauan Bangka Belitung.

Tabel 3 menunjukkan bahwa secara keseluruhan, penduduk Indonesia memiliki mutu gizi, keragaman, dan keseimbangan konsumsi pangan kelompok pangan hewani paling banyak dengan kategori rendah dan kategori cukup pada tahun 2019 maupun tahun 2020.

Tabel 3 Proporsi Skor PPH Kelompok Pangan Hewani (persen/kapita/hari)

\begin{tabular}{lrrrrrr}
\hline \multirow{2}{*}{ Kategori } & \multicolumn{2}{c}{ Kota } & \multicolumn{2}{c}{ Desa } & \multicolumn{2}{c}{ Total } \\
\cline { 2 - 7 } & $\mathbf{2 0 1 9}$ & $\mathbf{2 0 2 0}$ & $\mathbf{2 0 1 9}$ & $\mathbf{2 0 2 0}$ & $\mathbf{2 0 1 9}$ & $\mathbf{2 0 2 0}$ \\
\hline Sangat rendah $(<55 \%)$ & - & 2,94 & 27,27 & 30,30 & 11,76 & 11,76 \\
Rendah (55-69\%) & 32,35 & 23,53 & 45,45 & 42,42 & 35,29 & 32,35 \\
Cukup (70-84\%) & 35,29 & 41,18 & 15,15 & 15,15 & 35,29 & 32,35 \\
Baik ( $\geq 85 \%)$ & 32,35 & 32,35 & 12,12 & 12,12 & 17,65 & 23,53 \\
\hline
\end{tabular}

Sumber: BPS, 2019-2020 diolah (2021)

Jika dilihat berdasarkan wilayah, kelompok kategori rendah mendominasi masyarakat perdesaan sedangkan kelompok kategori cukup mendominasi masyarakat perkotaan.

Peranan Ikan dalam Pemenuhan Kebutuhan Konsumsi Pangan Hewani

\section{Pangsa Pengeluaran Ikan}

Tabel 4 Pangsa Pengeluaran Pangan dan Non Pangan (persen)

\begin{tabular}{cccc}
\hline \multirow{2}{*}{$\begin{array}{c}\text { Wilaya } \\
\text { / Tahun }\end{array}$} & \multicolumn{2}{c}{ Pangsa } & \\
\cline { 2 - 3 } & $\begin{array}{c}\text { Panga } \\
\mathbf{n}\end{array}$ & $\begin{array}{c}\text { Non } \\
\text { Panga } \\
\mathbf{n}\end{array}$ & $\begin{array}{c}\text { Total } \\
\text { Pengeluaran } \\
(\mathbf{R p} / \mathbf{k a p i t a} / \mathbf{b l n})\end{array}$ \\
\hline Kota & & & \\
2019 & 45,90 & 54,10 & 1.388 .212 \\
2020 & 46,05 & 53,95 & 1.455 .637 \\
Desa & & & \\
2019 & 55,59 & 44,41 & 882.829 \\
2020 & 55,49 & 44,51 & 933.695 \\
Total & & & \\
2019 & 49,14 & 50,86 & 1.165 .241 \\
2020 & 49,22 & 50,78 & 1.225 .685 \\
\hline
\end{tabular}

Sumber: BPS, 2019-2020 diolah (2021)

Proporsi pengeluaran makanan terhadap total pengeluaran atau pangsa (share) pengeluaran pangan merupakan indikator dini yang mampu menggambarkan derajat ketahanan pangan di tingkat rumah tangga. Pangsa pengeluaran pangan berhubungan negatif dengan ketahanan pangan. Semakin tinggi pangsa pengeluaran pangan, maka akan mengurangi ketahanan pangan (BPS, $\left.2020^{\mathrm{a}}\right)$.

Tabel 4 menunjukkan bahwa masyarakat perdesaan dengan tingkat pendapatan yang lebih rendah memiliki proporsi pengeluaran untuk pangan yang lebih besar dibandingkan masyarakat perkotaan. Pada tahun 2020, pangsa pengeluaran pangan di wilayah perdesaan meningkat sedangkan di perkotaan menurun dibandingkan tahun sebelumnya.

Perbedaan tingkat pendapatan penduduk di wilayah perkotaan dan 
perdesaan dari pengeluaran menimbulkan tanggapan yang berbeda dalam menangani upaya pemenuhan kebutuhan konsumsinya. Hal ini sesuai dengan Hukum Engel yang menyebutkan pada umumnya bila selera tidak berbeda maka pengeluaran pangan rumah tangga akan meningkat sejalan dengan meningkatnya pendapatan, akan tetapi proporsi pengeluaran pangan tersebut dari total pendapatan akan menurun (Mankiw, 2007 dalam Mayasari, dkk., 2018).

Struktur pengeluaran menurut kelompok pangan atau komoditas memberikan informasi yang lebih komprehensif tentang deskripsi alokasi anggaran dan kesejahteraan masyarakat. Disamping merefleksikan tingkat kesejahteraan (dengan pertimbangan faktor tingkat pendapatan), pilihan pangan juga diwarnai oleh pertimbangan faktor sosial budaya seperti pendidikan, pemahaman tentang masalah gizi dan kesehatan, serta adat istiadat setempat. Faktor sosial ini akan memberikan apresiasi yang berbeda terhadap kelompok komoditas tertentu seperti halnya untuk komoditas ikan (Suryawati, dkk., 2005 $)$.

\section{Tabel 5 Pangsa Pengeluaran Ikan}

\begin{tabular}{|c|c|c|c|c|c|}
\hline & Vilayah & Pengeluaran Ikan & Pangsa pengeluara & an terhadap & geluaran \\
\hline & Tahun & (Rp/kap/bln) & Pangan hewani $(\%)$ & Pangan (\%) & Total $(\%)$ \\
\hline Kota & & & & & \\
\hline & 2019 & 48.782 & 41,53 & 7,66 & 3,51 \\
\hline & 2020 & 50.046 & 40,55 & 7,47 & 3,44 \\
\hline Desa & & & & & \\
\hline & 2019 & 40.898 & 48,93 & 8,33 & 4,63 \\
\hline & 2020 & 42.156 & 47,83 & 8,14 & 4,51 \\
\hline Total & & & & & \\
\hline & 2019 & 45.304 & 44,19 & 7,91 & 3,89 \\
\hline & 2020 & 46.570 & 43,17 & 7,72 & 3,80 \\
\hline
\end{tabular}

Sumber: BPS, 2019-2020 diolah (2021)

Tabel 5 menunjukkan bahwa telah terjadi peningkatan pengeluaran untuk pangan ikan pada tahun 2020 baik di wilayah perkotaan maupun perdesaan dibandingkan tahun 2019. Namun, apabila ditinjau berdasarkan proporsi pengeluaran ikan terhadap pengeluaran pangan hewani, pengeluaran pangan, dan pengeluaran total telah terjadi penurunan pangsa pengeluaran ikan di kedua wilayah pada tahun 2020.
Meskipun demikian, tingkat pengeluaran ikan di perdesaan lebih rendah dibandingkan di perkotaan. Lebih lanjut, konsumsi ikan di wilayah perkotaan pada tahun 2020 menurun dibandingkan tahun sebelumnya. Namun, tingkat pengeluaran ikan pada tahun 2020 meningkat walaupun jumlah konsumsinya menurun. Hal tersebut dapat terjadi disebabkan oleh perbedaan jenis ikan yang dikonsumsi oleh penduduk di wilayah perkotaan dan perdesaan. 
Perbedaan harga ikan di tingkat konsumen juga turut memengaruhi fenomena tersebut.

Berdasarkan kuintil pengeluaran, telah terjadi penurunan pangsa pengeluaran untuk ikan di setiap kuintil pengeluaran pada tahun 2020 dibandingkan tahun sebelumnya. Selain itu, pangsa pengeluaran ikan merupakan yang tertinggi dibandingkan pangan hewani lainnya dari setiap kuintil pengeluaran baik pada tahun 2019 maupun tahun 2020 (BPS, 2019ª $\left.2020^{\mathrm{a}}\right)$.

Pola makan sehat lain yang dipilih seperti yang dikembangkan oleh komisi EAT-Lancet dimungkinkan turut memengaruhi perbedaan pangsa pengeluaran untuk konsumsi ikan. (EATLancet, 2019; FAO, et al, 2020).

\section{Tingkat Konsumsi Ikan dan}

\section{Partisipasi Konsumsi Ikan}

Diketahui ikan merupakan pangan hewani yang mempunyai nutrisi tinggi, sumber asam essensial, serta rendah kandungan lemak jenuh yang menjadikan ikan lebih menyehatkan dibandingkan dengan protein hewani lainnya (Susanto \& Fahmi, 2012; Djunaidah, 2017). Konsumsi ikan dapat melindungi manusia dari penyakit yang disebabkan karena perubahan gaya hidup di banyak negara industri di dunia (Larsen et al., dalam Susanto \& Fahmi, 2012).

Zat yang terkandung dalam ikan bermanfaat bagi kesehatan serta mampu mereduksi dan mencegah berbagai penyakit seperti penyakit jantung, stroke, arthritis, inflamasi, kanker, kondisi psikologis, diabetes, dan sindrom metabolik. (Djunaidah, 2017; Kurnia, dkk., 2018; Patel et al., 2010; Noer, dkk., 2020). 

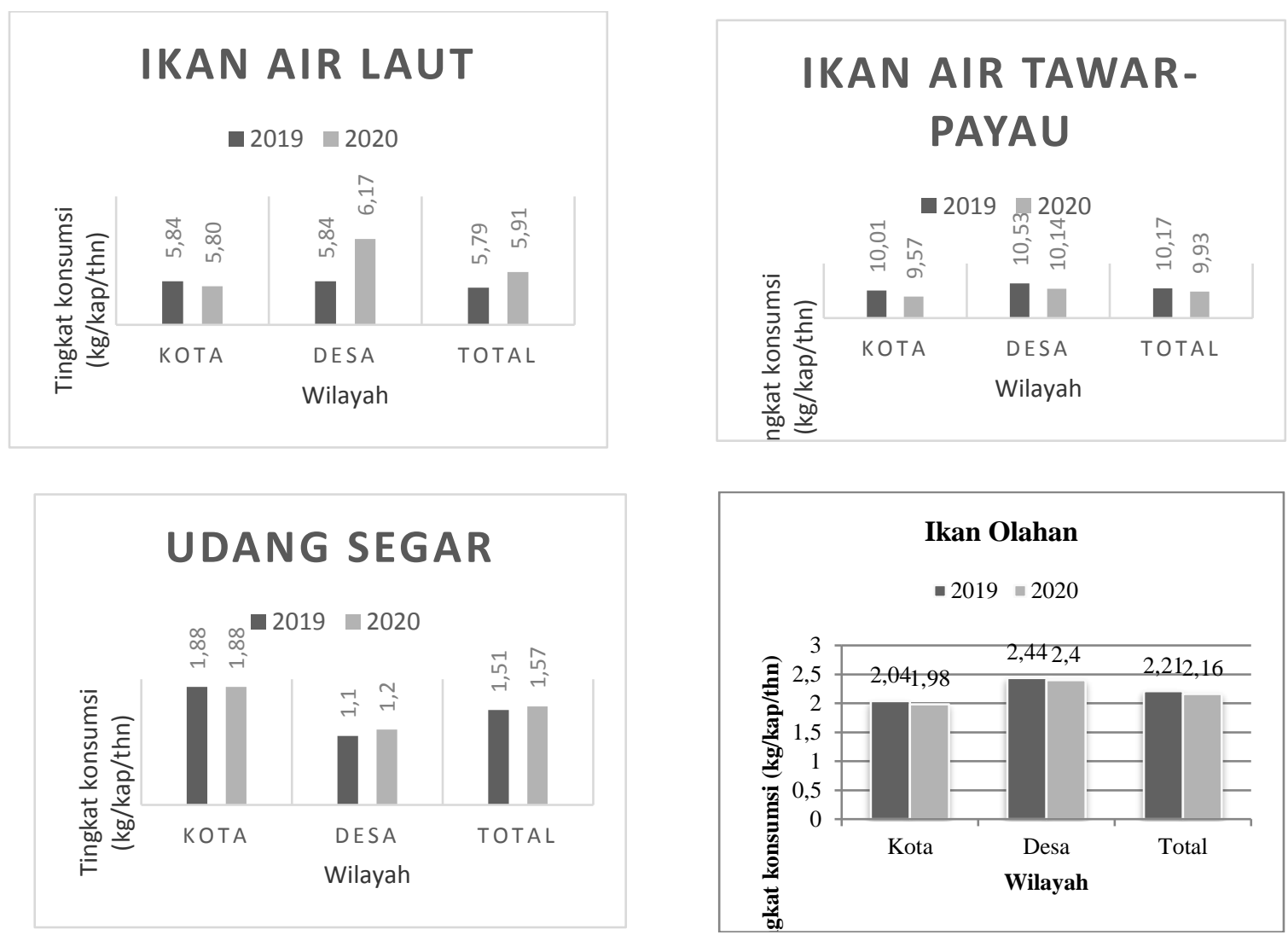

\section{Gambar 1 Tingkat Konsumsi Ikan}

(Sumber: BPS, 2019-2020 diolah 2021)

Tingkat konsumsi ikan di wilayah perdesaan di Indonesia tahun 2019-2020 lebih besar dibandingkan dengan wilayah perkotaan, kecuali untuk kelompok udang segar. Lebih lanjut, pada umumnya terjadi penurunan tingkat konsumsi ikan pada tahun 2020 dibandingkan tahun sebelumnya, kecuali untuk kelompok ikan air laut di wilayah perdesaan mengalami peningkatan dan kelompok udang segar di wilayah perkotaan yang mengalami stagnasi.

Penelitian Arthatiani, dkk. (2018) berdasarkan data Susenas tahun 2016 menunjukkan bahwa konsumsi ikan per kapita kelompok ikan air laut mencapai
$22,1 \mathrm{~kg} / \mathrm{tahun}$, kelompok ikan air tawar mencapai 16,75 kg/tahun, kelompok udang segar mencapai 9,58 kg/tahun, dan kelompok ikan olahan mencapai 4,22 $\mathrm{kg} /$ tahun. Dengan rata-rata konsumsi ikan mencapai 25,77 kg/kapita/tahun. Kemudian Suryawati, dkk. (2005 $)$ menemukan bahwa tingkat konsumsi ikan di daerah perkotaan umumnya lebih besar jika dibandingkan dengan daerah pedesaan, kecuali untuk kelompok ikan yang diawetkan (ikan kaleng dan olahan).

Ikan tongkol/tuna/cakalang/ikan kayu dan kembung, lema/tatare, banyar/banyara merupakan jenis ikan air laut yang cukup digemari masyarakat 
Indonesia baik yang tinggal di wilayah perkotaan maupun di wilayah perdesaan.

Ikan lele, mas, bandeng, dan mujair/nila merupakan jenis ikan air tawarpayau yang cukup digemari masyarakat Indonesia baik yang tinggal di wilayah perkotaan maupun perdesaan. Hal ini sesuai dengan penelitian Ariani, dkk. (2018) berdasarkan data Susenas tahun 2014 yang menemukan bahwa tingkat partisipasi konsumsi ikan lele merupakan yang tertinggi pada kelompok ikan tawar yaitu sebesar 8,2 persen. Kemudian, disusul dengan ikan mas dengan tingkat partisipasi konsumsinya mencapai 5,5 persen.

Udang, lobster, dan cumi-cumi, sotong, gurita merupakan jenis kelompok udang segar yang cukup digemari masyarakat Indonesia baik yang tinggal di wilayah perkotaan maupun perdesaan. Hal ini sesuai dengan penelitian Arthatiani, dkk.
(2018) berdasarkan data Susenas tahun 2016 menunjukkan tingkat partisipasi konsumsi kelompok udang segar mencapai 10,39 persen.

Ikan teri/tongkol/tuna/cakalang diawetkan merupakan jenis ikan olahan yang cukup digemari masyarakat Indonesia baik yang tinggal di wilayah perkotaan maupun perdesaan. Penelitian Arthatiani, dkk. (2018) menunjukkan tingkat partisipasi konsumsi kelompok ikan olahan mencapai 40,08 persen.

3. Sumbangan Ikan terhadap Kecukupan Konsumsi Energi dan Protein

Secara keseluruhan, perkembangan konsumsi energi dari pangan ikan penduduk Indonesia menurun dibandingkan tahun sebelumnya. Namun, terjadi hal sebaliknya untuk wilayah perdesaan meskipun peningkatannya tidak begitu banyak, Tabel 6.

Tabel 6 Konsumsi Energi dari Pangan Ikan (kkal/kapita/hari)

\begin{tabular}{lcccccr}
\hline \multirow{2}{*}{ Wilayah } & \multicolumn{2}{c}{ Kota } & \multicolumn{2}{c}{ Desa } & \multicolumn{2}{c}{ Total } \\
\cline { 2 - 7 } & $\mathbf{2 0 1 9}$ & $\mathbf{2 0 2 0}$ & $\mathbf{2 0 1 9}$ & $\mathbf{2 0 2 0}$ & $\mathbf{2 0 1 9}$ & $\mathbf{2 0 2 0}$ \\
\hline Sumatera & 64,39 & 64,64 & 65,60 & 66,33 & 63,21 & 63,98 \\
Jawa & 40,13 & 39,08 & 31,29 & 31,30 & 40,24 & 39,10 \\
Bali-NT & 50,92 & 52,05 & 47,97 & 47,81 & 47,67 & 47,85 \\
Kalimantan & 70,44 & 70,66 & 72,29 & 72,68 & 71,48 & 71,60 \\
Sulawesi & 85,93 & 79,23 & 81,18 & 79,23 & 82,90 & 79,19 \\
Maluku & 86,63 & 86,05 & 86,28 & 89,17 & 86,15 & 88,23 \\
Papua & 84,32 & 81,17 & 59,59 & 61,00 & 67,46 & 67,59 \\
\hline Indonesia & $\mathbf{4 9 , 1 2}$ & $\mathbf{4 7 , 8 9}$ & $\mathbf{5 2 , 3 7}$ & $\mathbf{5 2 , 4 4}$ & $\mathbf{5 0 , 5 5}$ & $\mathbf{4 9 , 8 9}$ \\
\hline
\end{tabular}

Sumber: BPS, 2019-2020 diolah (2021)

Apabila ditinjau berdasarkan gugus pulau, wilayah Maluku memiliki konsumsi energi dari pangan ikan paling tinggi dibandingkan wilayah lainnya dengan 
sumbangan energi dari pangan ikan yang dikonsumsi terhadap total kecukupan energi mencapai lebih dari 4 persen. Sedangkan, wilayah Jawa memiliki konsumsi energi dari pangan ikan paling rendah dibandingkan wilayah lainnya dimana sumbangan energi dari pangan ikan yang dikonsumsi terhadap total kecukupan energi kurang dari 2 persen.
Konsumsi protein diperlukan sebanyak 65 persen berasal dari hewan dan 35 persen berasal dari nabati. Artinya, dibutuhkan 37,05 gram/kapita/hari untuk memenuhi AKP harian dari protein hewani, dan sebesar 60 persen berasal dari jenis ikan (22,23 gram/kapita/hari) (Permenkes, 2019; Suryawati, dkk., 2005ª).

Tabel 7 Konsumsi Protein dari Pangan Ikan (gram/kapita/hari)

\begin{tabular}{lrrrrrr}
\hline \multirow{2}{*}{ Wilayah } & \multicolumn{2}{c}{ Kota } & \multicolumn{2}{c}{ Desa } & \multicolumn{2}{c}{ Total } \\
\cline { 2 - 7 } Sumatera & $\mathbf{2 0 1 9}$ & $\mathbf{2 0 2 0}$ & $\mathbf{2 0 1 9}$ & $\mathbf{2 0 2 0}$ & $\mathbf{2 0 1 9}$ & $\mathbf{2 0 2 0}$ \\
Jawa & 10,99 & 11,02 & 10,92 & 10,99 & 10,67 & 10,79 \\
Bali-NT & 6,92 & 6,75 & 5,13 & 5,17 & 6,88 & 6,73 \\
Kalimantan & 8,81 & 9,00 & 8,09 & 8,04 & 8,13 & 8,14 \\
Sulawesi & 11,95 & 12,00 & 11,77 & 11,82 & 11,87 & 11,89 \\
Maluku & 14,24 & 13,15 & 13,35 & 13,05 & 13,68 & 13,08 \\
Papua & 14,25 & 13,92 & 14,27 & 14,68 & 14,24 & 14,44 \\
\hline Indonesia & 14,55 & 14,06 & 9,97 & 10,31 & 11,44 & 11,52 \\
\hline
\end{tabular}

Sumber: BPS, 2019-2020 diolah (2021)

Secara keseluruhan, perkembangan

konsumsi protein dari pangan ikan menurun dibandingkan tahun sebelumnya. Namun, terjadi hal sebaliknya untuk wilayah perdesaan meskipun peningkatannya tidak begitu signifikan. Untuk wilayah perkotaan pada tahun 2019-2020 konsumsi protein dari pangan ikan paling tinggi yaitu wilayah perkotaan di Papua mencapai 24,67-25,53 persen dari total kecukupan protein. Sedangkan, wilayah Jawa memiliki konsumsi protein dari pangan ikan paling rendah dibandingkan wilayah lainnya baik menurut wilayah perdesaan maupun wilayah perkotaan.

Penduduk wiilayah Jawa lebih banyak mengonsumsi daging (50,83-102,23 $\mathrm{kkal} /$ kapita/hari) dibandingkan penduduk wilayah Maluku

$(12,63-24,47$ $\mathrm{kkal} /$ kapita/hari). Begitu juga dengan konsumsi telur dan susu (BPS, 2020). Jika ditinjau dari tingkat produksi pangan hewani di kedua wilayah tersebut, produksi daging dan telur di wilayah Jawa lebih banyak dibandingkan di wilayah Maluku Bahkan, setelah dibandingkan dengan 
jumlah penduduknya pun masih memiliki perbedaan sekitar 5-10 kali lipat.

Sekilas, produksi perikanan di wilayah Jawa kebanyakan lebih tinggi dibandingkan di wilayah Maluku. Namun, jika dibandingkan dengan jumlah penduduk masing-masing, terlihat bahwa produksi perikanan di wilayah Maluku memiliki perbedaan sekitar 10-16 kali lipat dari wilayah Jawa.

Konsumsi ikan diperlukan untuk upaya perbaikan gizi yang sangat erat kaitannya dengan perbaikan kualitas SDM Indonesia demi keberhasilan pembangunan. Gizi yang memadai menjadikan angka kematian bayi dan balita menurun, kemampuan belajar anak sekolah meningkat, daya tahan fisik orang dewasa meningkat, dan angka kesakitan menurun yang berarti kualitas hidup meningkat. Prestasi kerja dan hari kerja yang meningkat dikarenakan kondisi tubuh yang baik itu menjadikan produktivitas SDM Indonesia meningkat dan pembangunan Indonesia baik dalam bidang ekonomi maupun yang lainnya tidak terhambat karena tenaga kerjanya memadai.

Penilaian asupan zat gizi dari konsumsi pangan kelompok orang atau masyarakat di suatu daerah/wilayah dengan menggunakan acuan kecukupan gizi perlu dilakukan secara berkala agar dapat digunakan untuk membuat rencana konsumsi pangan yang tepat sesuai dengan keunggulan wilayah. Selain energi dan protein dapat juga menilai konsumsi pangan menggunakan bagian dari AKG yang lain yang menjadi acuan saat ini mencakup semua zat gizi makro (lemak dan karbohidrat serta air), 14 vitamin, dan 14 mineral termasuk elektrolit.

\section{KESIMPULAN DAN SARAN}

Berdasarkan hasil penelitian dan pembahasan, dapat ditarik kesimpulan:

1. Pola konsumsi pangan hewani di Indonesia pada tahun 2019 dan tahun 2020 adalah ikan-daging-telur-susu baik di wilayah perkotaan maupun di wilayah perdesaan.

2. Tingkat keragaman dan keseimbangan konsumsi pangan hewani di Indonesia masih belum ideal (PPH pangan hewani $<24)$, meskipun telah terjadi sedikit perbaikan pada tahun 2020 dibandingkan tahun sebelumnya. Kelompok kategori rendah mendominasi masyarakat perdesaan sedangkan kelompok kategori cukup mendominasi masyarakat perkotaan.

3. Pangan ikan berperan dalam upaya pemenuhan kebutuhan konsumsi pangan hewani di Indonesia. Baik di wilayah perkotaan maupun di wilayah perdesaan, tingkat konsumsi ikan 
merupakan yang tertinggi dibandingkan

konsumsi pangan hewani lainnya.

\section{DAFTAR PUSTAKA}

Ariani, M., Suryana A., Suhartini S. H., \& Saliem H. P. (2018). Keragaan konsumsi pangan hewani berdasarkan wilayah dan pendapatan di tingkat rumah tangga. Jurnal Analisis Kebijakan Pertanian, 16(2): 143-158.

Arthatiani, F. Y., Kusnadi N., \& Harianto. (2018). Analisis pola konsumsi dan model permintaan ikan menurut karakteristik rumah tangga di Indonesia. Jurnal Sosial Ekonomi Kelautan dan Perikanan, 13(1): 7386.

BPS (Badan Pusat Statistik). (2019 $\left.{ }^{\mathrm{a}}\right)$. Pengeluaran untuk Konsumsi Penduduk Indonesia. Badan Pusat Statistik, Jakarta.

BPS. $\left(2020^{a}\right)$. Pengeluaran untuk Konsumsi Penduduk Indonesia. Badan Pusat Statistik, Jakarta.

BPS. $\left(2021^{\mathrm{a}}\right)$. Provinsi Kepulauan Bangka Belitung dalam Angka 2021. Badan Pusat Statistik, Bangka Belitung.

BPS. $\left(2021^{\mathrm{b}}\right)$. Provinsi Kepulauan Riau dalam Angka 2021. Badan Pusat Statistik, Riau.

Djunaidah, I. S. (2017). Tingkat konsumsi ikan di Indonesia: ironi di negeri bahari. Jurnal Penyuluhan Perikanan dan Kelautan, 11(1): 1224.

FAO, IFAD, UNICEF, WFP \& WHO. (2020). The State of Food Security and Nutrition in the World (SOFI)
2020. FAO; IFAD; UNICEF; WFP \& WHO, Rome.

Godfray, H. C. J. (2011). Food for thought. Proceedings of the National Academy of Sciences of the United States of America. 108(50): 1984519846.

Kementerian Kesehatan. (2019). Peraturan Menteri Kesehatan Republik Indonesia Nomor 28 Tahun 2019 tentang Angka Kecukupan Gizi yang dianjurkan untuk Masyarakat Indonesia. Kementerian Kesehatan, Jakarta.

Kurnia, A. R., Purba M. B., \& Gunawan, I M. A. (2018). Konsumsi ikan bersifat protektif terhadap diagnosis hipertensi di Indonesia. Jurnal Gizi Klinik Indonesia, 14(4): 163-174.

Lantarsih, R., Widodo, S., Darwanto, D. H., Lestari, S. B., \& Paramita, S. (2011). Sistem ketahanan pangan nasional : kontribusi ketersediaan dan konsumsi energi serta optimalisasi distribusi beras. Jurnal Analisis Kebijakan Pertanian, 9(1): 33-51.

Mayasari, D., Satria, D., \& Noor, I. (2018). Analisis pola konsumsi pangan berdasarkan status IPM di Jawa Timur. Jurnal Ekonomi dan Pembangunan Indonesia, 18(2): 191-213.

Noer, E. R., Syauqy, A., Rahadiyanti, A., Fitriani, D. Y., Ayustaningwarno, F., \& Fajrani, A. M. (2020). Hubungan konsumsi ikan terhadap risiko sindrom metabolik pada wanita obesitas abdominal. Journal of Nutrition College, 9(4): 279-284.

Patel, J.V., Tracey, I., Hughes, E. A., Lip, G. Y. (2010). Omega-3 
polyunsaturated acids and cardiovascular disease: notable ethnic diggerences or unfulfilled promise?. Journal of Thrombosis and Haemostatis, 8(10): 2095-2104.

Pertiwi, K. I., Hardinsyah, \& Ekawidyani, K. R. (2014). Konsumsi pangan dan gizi serta skor pola pangan harapan (PPH) pada anak usia sekolah 7-12 tahun di Indonesia. Jurnal Gizi dan Pangan, 9(2): 117-124.

Suryawati, S. H., Saptanto, S., \& Koeshendrajana, S. $\left(2005^{\mathrm{b}}\right)$. Analisis situasi pengeluaran dan konsumsi rumah tangga terhadap komoditas ikan di Indonesia. Jurnal Penelitian Perikanan Indonesia, 11(9): 63-72.

Suryawati, S. H., Saptanto, S., Ariani, M., \& Koeshendrajana, S. $\left(2005^{\mathrm{a}}\right)$. Peran ikan dalam pola konsumsi pangan hewani rumah tangga Indonesia: analisis data susenas 1996-2002. Jurnal Penelitian Perikanan Indonesia, 11(9): 41-62.
Susanto, E. \& Fahmi, A. S. (2012). Senyawa fungsional dari ikan: aplikasinya dalam pangan. Jurnal Aplikasi Teknologi Pangan, 1(4): 95-102.

Tanzil, L. \& Hafriani. (2021). Faktor-faktor yang mempengaruhi terjadinya stunting pada balita usia 24-59 bulan. Jurnal Kebidanan, 7(1): 2531.

Virgantari, F., Daryanto, A., Harianto, \& Kuntjoro, S. U. (2011). Dinamika konsumsi produk perikanan di Indonesia. Jurnal Ekologia, 11(2): 22-30.

Wahyuni, D., Purnastuti, L., \& Mustofa. (2016). Analisis elastisitas tiga bahan pangan sumber protein hewani di Indonesia. Jurnal Economia. 12(1): 43-53.

Widodo, Y., Sandjaja, \& Ernawati, F. (2017). Skor pola pangan harapan dan hubungannya dengan status gizi anak usia 0,5-12 tahun di Indonesia. Jurnal Penelitian Gizi dan Makanan. 40(2): 63-75. 